\title{
EXCURSION TO EAST GRINSTEAD AND WEST HOATHLY.
}

[In conjunction with the Croydon Microscopical Club.] Saturday, June $27 \mathrm{Th}, 1885$.

Directors: Edwand Easton, F.G.S., M.Inst.C.E., and the President.

(Roport by The President.)

The Members left London at 10.13, alighting at East Grinstead. They then walked along the railway for about half a mile eastwards to examine the section of Lower Tunbridge Wells Sand. The beds, which rise slightly to the East and North, are well exposed in an almost vertical face. A good example of a suall trough fault is here seen.

Returning to East Grinstead Station the party was joined by other Members, who came from London by a later train, making about 30 in all ; they then walked southryards to Kingscote Station. The new railway gives good sections of Grinstead Clay and Lower Tunbridge Wolls Sand, showing two faults, bringing the two divisions in contact. The shales of the Grinstead Clay yielded numerous specimens of Cypridea.

Leaving the rail at Kingscote, the walk was continued southwards to Selsfield Common. This is on the central anticlinal of the Weald, and on the central line of watershed. The surface here is rather over 600 feet above the sea; a fine view across the Weald is obtained, the Lower Greensand escarpment of Leith Hill and Hindhead standing out in a very striking manner. Here the President gave an address on the geology of the Weald, sketching out the mode of formation of the beds, the successive physical disturbances to which they have been subjected, and the mode by which the present surface-features have been produced.

Mr. J. W. Hulke, F.R.S., then described the Wealden Reptilia, referring especially to Iguanodon. Our knowledge of this genus is now fairly complete, very perfect skeletons having been found in Belgium which are now exhibited at the Brussels Museum. From these, and from other specimens of late years discovered in England, it is certain that several genera, described as distinct forms from detached vertebræ, must be abandoned. This reptile, which has many close relations to birds, is thought by some to 
have walked in a semi-erect position; but footprints show that it also often went on all fours.

Professor T. R. Jones followed with some remarks on the invertebrata of the Wealden Beds, showing that most of the shells are such as lived in fresh-water, which was either the estuary of a large river $0 r^{\circ}$ had connection with it.

The party then walked to Rockhurst, and were there received by Mr. Charles Hill, F.S.A., who conducted the Members through the grounds. The natural rocks are very fine, formed of the upper beds of the Lower Tunbridge Wells Sand. The beds are jointed, and the joints have been widened out by weathering. The spaces between the rocks are, however, partly due to gradual slipping. Mr. Hill during thirty years has noticed a considerable increase in many of the spaces. Hymenophyllum tunbridgense, Linn., and many species of moss, grow abundantly in the shady hollows of the rocks; and in one such nook refreshments were kindly provided by Mr. Hill.

The most famous rock is "Greatupon-Little," a mass of stone weighing between 400 and 500 tons, poised upon a small pedestal. This rock is covered with inscriptions, some of them dating 1622, 1702, 1705 ; and the names of Pitt and Fox, who are known to have visited the spot, were inscribed here, but, being on the side most exposed to the weather, they are now effaced.

On learing the grounds of Rockhurst the walk was continued to 
West Hoathly Station, where tea was provided at the Railway Inn. South of the station is a tunnel through the Wadhurst Clay, from the waste-heaps of which Cypridea, Cyrena, Paludina, with suncracks and otber markings, were obtained.

\section{REFERENCES.}

Ordnance Survey Map, New Series, sheet 202.

Geological Survey Map, sheets 5 and 6.

W. Topley.- “Geology of the Weald," 'Mem. Geol. Survey,' 1875, Chaps. VI., XV., Figs. 12, 51.

J. L. Lobley.-- " Report of the Excursion to Tilgate Forest," .'c. "Proc . Geol. Assoc.,' Vol. vii, pp. 372-375. (This Report, with the Section here reprodaced, describes a line of country a litile west of that now described; but it sufficiently represents the structure of the district.)

\section{EXCURSION TO ALDERSHOT AND WELLINGTON COLLEGE. \\ Saturday, July 11 th.}

Divector: Rev. A. Invina, B.Sc., B.A., F.G.S., of Wellington College.

\section{(Report by THE DIRECTOR.)}

The party leaving Waterloo arrived at Aldershot Station at 11.36, where they were met by the Director. The time allowed for the field-work indicated in the programme was found insufficient for that purpose ; so the sections about Cesar's Camp had to be deferred to another opportunity. With the great heat prevailing and the dry sandy nature of the district, the time at the disposal of the party was quite filled up in cxamining the sections near Aldershot Town, including (1) that at the foot of Redan Hill in the railway-cutting, where a bed of well-rolled pebbles occurs at the base of the Upper Bagshot Sands ; (2) the pebble-beds of Bagshot age, which crop out along the escarpment running east and west, on the north side of the town of Aldershot and surmounted by the Cambridge Hospital ; (3) the brickyard section, in which Bagshot Sands are seen (with a layer of iron-stone at the base of the Sands of the same nature as that which is deposited by peaty water's in some of the modern streams of the Bagshot District) lying on an eroded surface of London Clay, the latter being here worked extensively for bricks. Owing to 